\title{
Analysis the effect of investment on poverty in Indonesia year 1990-2016
}

\author{
Jen Surya ${ }^{1}$, Mohd. Nur Syechalad ${ }^{2}$, Abd. Jamal ${ }^{3}$, Muhammad Nasir ${ }^{4}$ \\ Economics Faculty of Syiah Kuala University, Indonesia ${ }^{2,3,4}$ \\ Serambi Mekah University Banda Aceh, Indonesia ${ }^{1}$
}

\begin{abstract}
The purpose of this study was to analysis the effect of investment on poverty in Indonesia using two analyzes : long-term equilibrium analysis with cointegration equation and short-term analysis with linear regression method ECM (Error Correction Model) period 19902016. Results show that domestic investment and foreign investment affect on poverty.
\end{abstract}

Keywords: domestic investment, foreign investment, poverty, cointegration test, and error correction model

\section{Introduction}

Indonesia generally has experienced a rapid and rapid urbanization process. Since the mid-1990s the absolute number of rural population in Indonesia has begun to decline and currently more than half the total population of Indonesia, except for some provinces, rural areas in Indonesia is relatively poorer than urban areas. Indonesia's rural poverty rate (the percentage of rural

population living below the national level of village poverty) fell to about 20 percent in the mid-1990s but soared when the Asian Financial Crisis occurred between 1997 and 1998, resulting in a 26 percent rise in value. After 2006, there has been a significant decrease in poverty rates both in rural and urban areas in Indonesia as shown in Table 1 below:

Table 1. Population Living Under the Poverty Line - Village and Town In Indonesia

\begin{tabular}{|l|c|c|c|c|c|c|c|c|c|c|}
\hline & 2005 & 2006 & 2007 & 2008 & 2009 & 2010 & 2011 & 2012 & 2013 & 2014 \\
\hline Rural Poverty & 20.0 & 21.8 & 20.4 & 18.9 & 17.4 & 16.6 & 15.7 & 14.3 & 14.4 & 13.8 \\
\hline Urban Poverty & 11.7 & 13.5 & 12.5 & 11.6 & 10.7 & 9.9 & 9.2 & 8.4 & 8.5 & 8.2 \\
\hline
\end{tabular}

Source: World Bank and Badan Pusat Statistik (BPS), 2016

The table above shows that in 2005 and 2006 there was an increase in the percentage of poverty rate, of which $1.8 \%$ was for rural poverty, and $1.8 \%$ of urban poverty, mainly due to the fuel subsidy cut by the SBY administration at the end of the year 2005 . The government does this because oil prices are increasing internationally, making the government forced to reduce fuel subsidies to ease the budget deficit. The consequence is double-digit inflation between 14 and 19 percent (yoy) occurred until October 2006.

Investment research has been undertaken by previous researchers, such as Lipsey and Sjoholm (2004) in his research that analyzed the role of foreign direct investment (FDI) in Indonesia contributing to employment for educated workers, and FDI also contributed to Indonesian manufacturing industry, from the technology side (Nasir, 2009:92). This study focuses not only on
FDI, but all existing investment, both domestic investment (including government investments) and foreign investment in poverty.

\section{Theoretical Review}

Poverty occurs not only because of the inability of income to meet consumption needs for decent living, as well as low levels of health and education, lack of security guarantees, and helplessness and low social strata. Khan (2010: 101) states: "Poverty is a dimension of income, including gender disparities, insecurity, powerlessness and social exclusion ".

The World Bank (1990) in its report to UN members entitled "Poverty and Human Development" says that: "The case for human development is not only or even primarily an economic one. "Human development is not only emphasized on the economic aspect, but more 
important is to prioritize the educational aspect universally for the self-interest of the poor to improve economic social life).

There are many explanations for the causes of poverty, but poverty is often linked to individual, or pathological causes, who see poverty as a result of the behavior, choice, or ability of the poor. Examples of poverty occur from behaviors and choices such as financial use that do not measure income, or the number of family members that is not proportional to household income. Sub-cultural causes (subcultural), where poverty occurs due to daily life, learned or run in the environment. Other examples such as poverty occur because of slavery, the consequences of others, war, government, and economy, as well as many other examples, even poverty is the result of social structure. Haughton (2007: 146) states "Poverty may be due to national, sector-specific, community, household, or individual characteristics".

Meanwhile, Chambers (1983: 149) asserted that the factors causing poverty are: the grid of poverty loss of rights or. wealth that is difficult to recover may be due to the urgency of need beyond its threshold of strength, such as predetermined expenditures, but the numbers are enormous, or suddenly faced with a great crisis. Typically the need to encourage someone in poverty, related to five things; customary obligations; disaster; physical disability, unproductive spending and extortion.

The above description shows that the cause of poverty is the internal factors of immediate needs that must be fulfilled but lack sufficient capability in trying to manage the resources possessed (inadequate skills, minimal level of education and others). External factors in the form of natural disasters such as the economic crisis, and the absence of a favorable policy in favor of opportunities and opportunities for the poor. Chamber (1983: 109) suggests five characteristics as disadventages covering the poor or poor families: (a) poverty, (b) physical weakness, (c) isolation, (d) powerlessness.

\section{Previous research}

According to Greenee and Villamueva (1991), Everhart (2001), Agenor (2002), Kok and Ersoy (2009) that to explain fluctuations in private investment in developing countries, it is necessary to take into account the influence of a number of variables in addition to the known variables theoretically, because of differences in economic conditions between developed and developing countries. Assante (2000), examines the determinants of private investment behavior in Ghana from 1970 to 1992. Assuming that macroeconomic instability has become a major obstacle to private investment.

Research conducted by Ouattara (2004) in Senegal, examines the model determinants of long-term private investment over the period 1970 - 2000 . First test the variables for the root unit using two, relative, new tests under the name Dickey-Fuller GLS de-trending test proposed by Eliot, et al (1996) and $\mathrm{Ng}$-Perron test by $\mathrm{Ng}$ and Perron (2001). The long-term investment equation is derived using Johansen's cointegration technique. (Johansen, 1988; Johansen and Juselius, 1990) and the latest test approach proposed by Pesaran et al. (2001).

Acosta and Loza (2005) examine the determinants of short and long term private investment in Argentina. This study provides an empirical analysis of the factors macroeconomic potentials that could potentially affect investment decisions at Argentina in perspective, short and medium term.

\section{Hypothesis}

Ho: Investments affect poverty

\section{Research Methods}

To test the hypothesis as an answer to the research problem is done by using the program EViews (Economic Views) version 9.00. In this research, there are two analysis that is long term balance analysis with using a cointegration equation and a term analysis short with linear regression method ECM (Error Correction Model). Before perform the first analysis conducted by the test kestasioneran data using unit root test, unit test of root test is done by using test method of ADF (Augmented Dickey Fuller) from Dickey-Fuller (1979), and PP test from Phillips and Peron. This means that the data used must be stationary, in other words the data has a variance that is not too large and has a tendency to approach the average value (Widarjono, 2007). According to Jamal (2015: 87) unit test of root test can also be done by the LLC, IPS, ADF, and PP methods. "Futhermore, unit root test is used to analyze the stationary data. PP at the level ".

\section{Results and Discussion}

To determine the effect of investment on poverty is done by testing Total Investment Against Poverty. 
Find out whether the total investment (Total Investment $=$ domestic investment and foreign investment) affects poverty. The results of if the data show related equations are as follows:

Table 2 : Result of Equation Test of Influence of Total Investment to Poverty

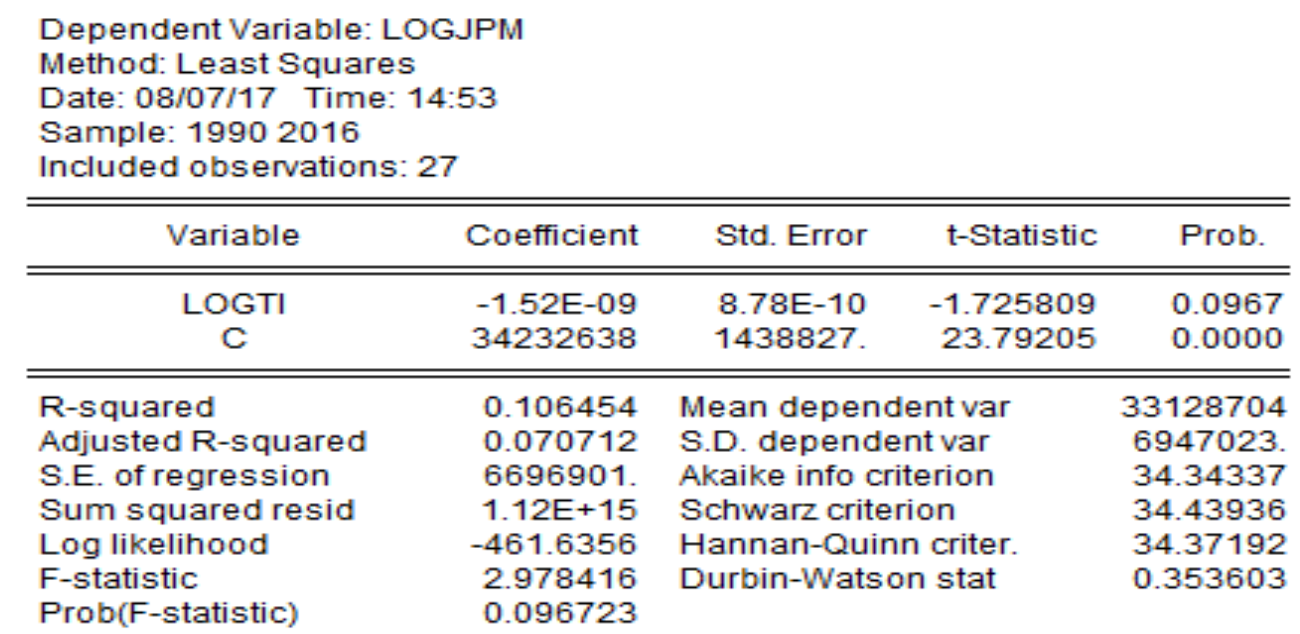

The data can be represented in equations with the estimation of the equation as follows:

LOGJPM $=$ C (1) LOGTI + C (2)

The next step enters the values that have been obtained into the equation, the result is as follows:

\section{LOGJPM $=-1.5153752294 \mathrm{e}-09 *$ LOGTI + 34232637.6611}

The above equation shows that there is a negative relationship between investment and poverty. Where any increase of $\mathrm{Rp} 1$ from investment will result in poverty reduction of 1.5154 . These results also corroborate the theory that poverty will diminish as investment increases.

The result of statistical test of R-squared value is 0,1065 and Adjusted R-squared value is 0,0707 . This result also shows that the proposed model is not feasible, considering that only $10.65 \%$ can only be explained by the model. The rest is explained by other variables $(89.35 \%)$, therefore another variable is needed to explain poverty.

\section{a) Multicolinearity Test}

Multicolinearity test is done to find out whether the variant coefficient of the equation has multicollinearity or not. To find out is done Variance Inflation Factor (VIF) test. The VIF test results show that the centered VIF value of the total investment (TI) variable has a coefficient of no more than 10. In theory if the value of centered VIF is not more than 10 then there is no multicollinearity. The VIF test result of the total investment coefficient of 1 , means there is no multicollinearity between the total investment variable and poverty.

\section{Table 3: VIF Test Result, Total Investment Coefficient}

Variance Inflation Factors

Date: 08/07/17 Time: 15:49

Sample: 19902016

Included observations: 27

\begin{tabular}{|c|c|c|c|}
\hline Variable & $\begin{array}{c}\text { Coefficient } \\
\text { Variance }\end{array}$ & $\begin{array}{c}\text { Uncentered } \\
\text { VIF }\end{array}$ & $\begin{array}{c}\text { Centered } \\
\text { VIF }\end{array}$ \\
\hline LOGTI & $7.71 \mathrm{E}-19$ & 1.246330 & 1.000000 \\
\hline C & $2.07 \mathrm{E}+12$ & 1.246330 & NA \\
\hline
\end{tabular}

\section{a) Heteroskedasticity test}

The result of heteroskedasitas test shows that there is no heteroskedasitas on the investment determinant model proposed. This can be seen from the value of F Count of 2.357 when compared with the value Probability F Table of 0.1373 . In theory if the probability value of $\mathrm{F}$ Calculate is greater than the level of $\alpha=5 \%$, it can be concluded there is no heteroskedasitas in equation model. The following 
test results can be seen in Table 4 of the

$(235.7 \%)>$ of F Table $(13.73 \%)$ :

Heteroskidity Test, showing that F Count

Table 4: Heteroskedasticity test

\begin{tabular}{lrlr} 
Heteroskedasticity Test: Breusch-Pagan-Godfrey & \\
\hline \hline F-statistic & 2.357361 & Prob. F(1,25) & 0.1373 \\
Obs*R-squared & 2.326568 & Prob. Chi-Square(1) & 0.1272 \\
Scaled explained SS & 2.062732 & Prob. Chi-Square(1) & 0.1509 \\
\hline \hline
\end{tabular}

\section{c. Autocorrelation Test}

Autocorrelation test can be done by using several approaches, one of them through LM Test. The LM Test results show probability $F(2.23)$ calculated statistics of 0.0000 or $0 \%$. Theoretically, if the probability value of $\mathrm{F}$ statistic count is greater than F Table with the level of $\alpha=5 \%$, then based on the hypothesis test, $\mathrm{H} 0$ is accepted, which means there is no autocorrelation, otherwise if Probability $\mathrm{F}$ Count is smaller then concluded autocorrelation occurs. Based on this it can be concluded that $\mathrm{HO}$ on the multiple regression equation of total investment is rejected, because it happened autokorelasi, because probability $\mathrm{F}$ count statistic bigger than $\mathrm{F}$ Table at level of $\alpha=5 \%$ that is equal to 3,42 , where $(0 \%<3,42)$.

\section{Tabel 5: Uji LM Test, Total Investasi}

Breusch-Godfrey Serial Correlation LM Test:

\begin{tabular}{llll}
\hline \hline F-statistic & 31.23693 & Prob. F(2,23) & 0.0000 \\
Obs*R-squared & 19.73462 & Prob. Chi-Square(2) & 0.0001
\end{tabular}

\section{d. Normality test}

To find out whether the residual data of the total investment obtained is normal, then the Normality Test is performed. The next step is to compare the value of Jarque-Bera (JB) count with the level of $\alpha$ $=5 \%$. If: JB calculates $>5 \%$, it can be concluded that the residual value of the normal distributed variable. Graph 4.1 The histogram diagram below shows that: $\mathrm{JB}>\alpha$, where $\mathrm{Jb}=0,5092$ which means $50.92 \%$. It means that the residual value is normally distributed and this shows that the classical assumptions about normality have been met.

\section{Graph 1: Histogram diagram Test of Residual Normality Effect of Investment on Poverty}

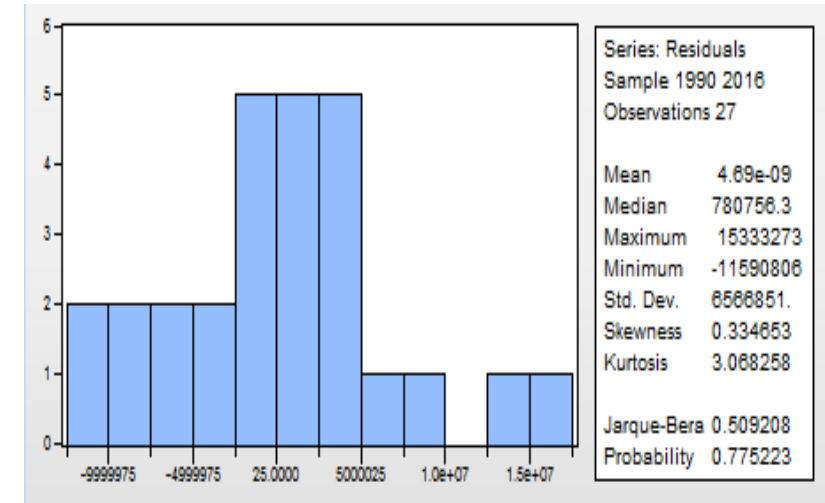

The independent variable of this equation is only Total Investment, besides the constants of course. When considering the value of $t$ arithmetic shows the value of -1.726 with probability $t$ arithmetic 0,0967 , while $t$ table with significance level $\alpha=5 \%$ and confidence level 90\%, and Degree of Freedom $(D F)=25$, where $n=27 \mathrm{k}=2(\mathrm{df}=\mathrm{n}-\mathrm{k})$, then obtained t table value equal to value 1,708 . The results showed the $t$ count of 1.726> $t$ table of 1.708. This shows that investment affects poverty.

\section{Conclusion}

Simultaneously (F Test Result) shows that investment (total investment $=$ domestic investment and foreign investment) effect on poverty. This study uses data with variants of variables that are very much different, it is better fore in determining the variables sought variant data that is not much different.

\section{References}

[1] Acosta, P. \& Loza, A., 2005. Short and Long Run Determinants of Private in Argentina. Journal of Applied Economic, VIII, pp.389406.

[2] Ang, J.B., 2009a. Determinants of Private Investment in Malaysia: What Causes the 
Postcrisis Slumps? Contemporary Economic Policy, 28(3), pp.378-391.

[3] Ang, J.B., 2009b. Private Investment and Financial Sector Policies in India and Malaysia. Journal of World Development, Volume 37 Number7, pp.1261-1273.

[4] Asante, Y., 2000. Determinants of Private Investment Behaviour., African Economic Research Consortium, Nairobi March.

[5] Badan Pusat Statistik Indonesia, 2016 Statistik Indonesia., Statistical Yearbook of Indonesia.

[6] Chambers, Robert, (1983). Rural Development, Putting the Last First, Longman: London.

[7] Giannaros, D., Kolluri, B. \& Panik, M., 1999. The Effects Of Government Spending On Capital Investment: International Economic Journal, 13(1), pp.45-55.

[8] Greene, Joshua \& Villanueva, Delano., 1991., Private Investment in Developing Countries: An Empirical Analysis., IMF Staff Papers., Volume 38. Nomor 1. Pp: 33 - 58.

[9] Jamal A (2015) Did Indonesia Political Economic Reform Reduce Economic Growth Disparities Among Region. DLSU Business \& Economic. 25. 1. Pp.81-94.

[10]

Ersoy, B.A., 2009. Analyses of FDI determinants in developing countries. International Journal of Social Economics, 36(1/2), pp.105-123.

[11] Nasir M (2009), The Role of Foreign Direct Investment on Indonesian Economic Growth, Jurnal Ekonomi dan Bisnis: p. 92

[12] Ouattara, B., 2004. Modelling the Long Run Determinants of Private Investment in Senegal. CREDIT Research Paper, No.05/04, Centre for Research in Economic Development and International Trade, University of Nottingham.

[13] United Nations, (2004), Human Rights and Poverty Reduction, A Conceptual Frame Work, New York and Geneva.

[14] Widarjono, Agus., 2007. Ekonometrika Teori dan Aplikasi untuk Ekonomi dan Bisnis, Edisi kedua, Ekonesia Fakultas Ekonomi UII Yogyakarta. 